\title{
Effect of Hot Deformation on Bainite Structure in Low Carbon Steels
}

\author{
Kazuki FUJIWARA, Shuji OKAGUCHI and Hiroo OHTANI
}

Iron and Steel Research Laboratories, Sumitomo Metal Industries, Ltd., Fuso-cho, Amagasaki, Hyogo-ken, 660 Japan.

(Received on March 9, 1995; accepted in final form on May 26, 1995)

\begin{abstract}
Effects of deformation in unrecrystallized austenite region on bainite microstructure were investigated in low carbon $\mathrm{Nb}-\mathrm{B}$ bearing steels. Particular emphases were placed on the variation of the morphology of bainitic ferrite in isothermally transformed specimen.

SEM observation shows that, in the case of non-deformation, a number of straightly elongated bainitic ferrite laths form parallel from austenite grain boundaries, showing an aspect of typical upper bainite structure. In the case of $30 \%$-deformation, although bainitic ferrite laths are shaped like curves of bows, the deformation has a little influence on their length. In the case of $50 \%$-deformation, on the contrary, the length is significantly decreased in the growth direction of the lath. Furthermore, the number of bainitic ferrite lath in a "bainite

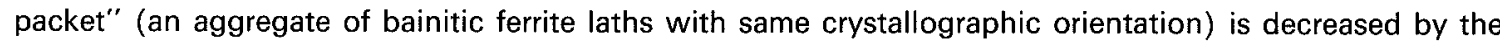
enhancement of the nucleation within austenite grains. The decrease of both the length and the number of bainitic ferrite lath leads to complicate the appearance of a microstructure.

TEM observation, however, confirmed that those bainitic ferrite laths were also surrounded by two sets of parallel planes close to $\{451\}_{\alpha}$ in the case of $50 \%$-deformation, as previously reported for typical bainitic ferrite laths in the case of non-deformation. Therefore it suggests that bainitic ferrite laths transformed from heavily deformed austenite has also the same crystallographic characteristics with typical one.
\end{abstract}

KEY WORDS: bainite; bainitic ferrite; low carbon; deformed austenite; bainite packet; habit plane.

\section{Introduction}

Bainite structure which has high strength in low carbon low alloy steels have taken and will take an important role for the practical use in many constructions. ${ }^{1-3)}$ Furthermore, recent studies on bainite structure have aimed at clarifying its reaction mechanism and also establishing its terminology in ultra low carbon steels.

Some of the TTT diagrams for low carbon low alloy steels consist of $2 \mathrm{C}$-curves showing the start of ferrite and bainite transformation. The flat top lower C-curve is accompanied by the appearance of Bs temperature ${ }^{4)}$ (the highest temperature where bainite transformation occurs). ${ }^{2,5)}$

The morphology of bainite structure formed at temperatures between $\mathrm{Bs}$ and $\mathrm{Ms}$ are classified into three types of upper bainite named BI-BIII. ${ }^{6}$ Optical micrographs of upper bainite structure describe that bainitic ferrite shows a lathlike morphology and generally discontinues its growth on the austenite grain boundaries. BI type is characterized by the cementite free bainitic ferrite lath transformed at high temperatures just below the Bs. In contrast, BII and BIII types are duplex structures of lathlike ferrite plates and cementite particles. Although BIII type whose cementite platelets precipitate in the ferrite laths should be classified into lower bainite from the viewpoint of Mehl's definition, ${ }^{7)}$ the reason why the new classification of terminology has been necessary is that BI-BIII bainitic ferrite laths reveal the same crystallographic features with each other. ${ }^{6)}$

As mentioned above, many studies on bainite structure have clarified the morphology and also established the terminology in isothermal heat treatment. ${ }^{6-9)}$ However the application of accelerated cooling after controlled rolling which has improved the balance of strength and toughness of bainitic steels ${ }^{1-3,10)}$ makes the microstructures considerably dissimilar to those in the conventional quench and temper process. ${ }^{2,11)}$ Although some of these complicated microstructures have been called " $\mathrm{Zw}^{12}$ )", the nature of them have never been clarified.

From the viewpoint of the practical use, on the contrary, it is known that each bainite packet (an aggregate of bainitic ferrite laths formed parallel with same crystallographic orientation) determines an effective grain size in bainite or bainite-martensite duplex structures. Therefore, the toughness of bainitic steels depends on the size of bainite packets whose boundaries can be the resistance for crack propagation. ${ }^{13,14)}$ Further detailed analysis ${ }^{15}$ clarified that the size of packets whose orientation differed more than 9 degrees from the adjacent packets consisted with the unit crack length. Therefore, it is effective to clarify their manner of microstructural refinement by the deformation in unrecrystallized austenite region in order to improve the toughness of steel plates.

There are several studies ${ }^{16-19)}$ on the kinetics and the morphology of bainite transformed from unrecrystallized 
Table 1. Chemical compositions of steels. (mass\%)

\begin{tabular}{|c|c|c|c|c|c|c|c|c|c|c|c|}
\hline & C & $\mathrm{Si}$ & $\mathrm{Mn}$ & $\mathrm{P}$ & $\mathrm{S}$ & $\mathrm{Ni}$ & $\mathrm{Nb}$ & $\mathrm{Ti}$ & $\mathbf{B}$ & sol-Al & $\mathrm{N}$ \\
\hline 1 & 0.18 & 0.20 & 1.37 & 0.007 & 0.001 & 0.62 & 0.014 & 0.012 & 0.0008 & 0.026 & 0.0021 \\
\hline 2 & 0.10 & 0.20 & 1.34 & 0.007 & 0.001 & 0.62 & 0.015 & 0.012 & 0.0013 & 0.034 & 0.0004 \\
\hline 3 & 0.08 & 0.20 & 1.38 & 0.007 & 0.001 & 0.60 & 0.016 & 0.011 & 0.0009 & 0.033 & 0.0011 \\
\hline
\end{tabular}

austenite, which describe that the deformation has effects on the kinetics and the morphology of bainite. Edwards et al. ${ }^{17)}$ reported that a deformation shortened the incubation period for the transformation and reduced the plate size of lower bainite in a high carbon $\mathrm{Cr}-\mathrm{W}$ bearing steel. Tsuzaki et al. ${ }^{19)}$ described that a deformation shaped the microstructure like a curve of a bow in middle carbon high $\mathrm{Si}$ bearing steels.

However, those studies have never clarified the nature of the microstructure which is considered to be closely related to the bainite structure transformed from unrecrystallized austenite. This study clarifies the effects of deformation on bainite structure and also tries to propose the mechanism of microstructural refinement of bainite.

\section{Experimental Procedures}

Chemical compositions of the steels investigated are shown in Table 1. They contain $\mathrm{B}$ and $\mathrm{Nb}$ to increase the hardenability and to retard the recrystallization of austenite, respectively. The ingots were prepared in a 30 $\mathrm{kg}$ vacuum induction furnace and then rolled into $20 \mathrm{~mm}$ thick plates. Cylindrical specimens, $8 \mathrm{~mm}$ in diameter and $12 \mathrm{~mm}$ in length, were machined from the plates for the examination of TTT diagrams and the metallographic analysis. Heat patterns performed in this study is shown in Fig. 1. The specimens were austenitized at $1373 \mathrm{~K}$ for $300 \mathrm{~s}$ by induction heating in a vacuum chamber, deformed 0 to $75 \%$ at temperatures between 973 and $1173 \mathrm{~K}$ and were quenched by helium gas to temperatures between the upper limit of lower $\mathrm{C}$-curve (i.e. $\mathrm{Bs}^{4)}$ ) and Ms, and kept isothermally. After various period of time the specimens were quenched to room temperature by water spray in order to freeze untransformed austenite as martensite.

The decomposition of austenite during isothermal treatment was examined by means of dilatometry and microscopic observation. The microstructures were observed by optical and scanning electron micrographs after etching in $2 \%$ nital. The thin foils for transmission electron microscopy were prepared by a twin jet polishing technique using a $5 \%$ perchloric acid and $95 \%$ acetic acid electrolyte. The foils were examined by JEM-200CX transmission electron microscope operated at $200 \mathrm{kV}$.

\section{Results}

\subsection{Effects of Deformation on the Transformation Kinetics}

TTT diagrams for the steel 1 are shown in Fig. 2. This figure describes the effects of the amount of deformation at $1173 \mathrm{~K}$ on the start of transformation. In the case of non-deformation, the diagram consists of two C-curves

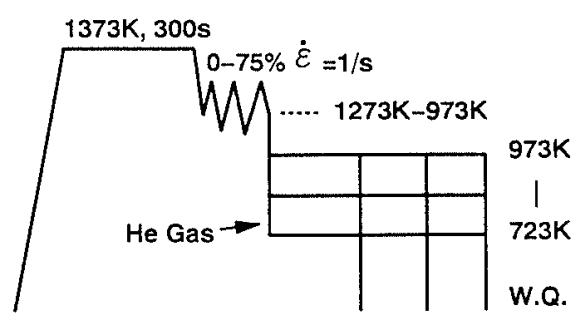

Fig. 1. Heat pattern performed.

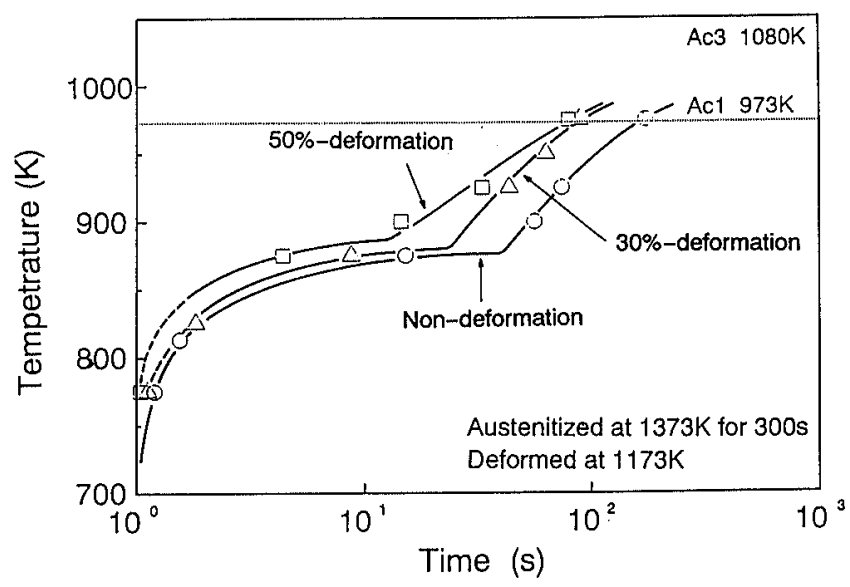

Fig. 2. TTT diagrams of steel 1 after 0 to $50 \%$-deformation at $1173 \mathrm{~K}$.

and Bs temperature is observed. Since the diagrams are clearly composed of two C-curves even in the cases of 30 and $50 \%$-deformation, Bs is clearly found in each case. Metallographic observation revealed that bainite and polygonal ferrite formed at the temperatures below and above the Bs, respectively. This figure shows that the change of incubation period of bainite transformation region is smaller than that of polygonal ferrite by the deformation in un-recrystallized austenite. It is confirmed that the effect of deformation on the nucleation and grwoth of bainite transformation differs from that of polygonal ferrite transformation above the Bs.

\subsection{Effects of Deformation on the Morphology of Bainitic Ferrite Lath}

3.2.1. Effect of Deformation on the Length of Bainitic Ferrite Lath

SEM micrographs of the specimens transformed at $848 \mathrm{~K}$ from 0,30 and $50 \%$-deformed austenite are shown in Figs. 3(a), 3(b) and 3(c), respectively, which show the effect of the amount of deformation in unrecrystallized austenite region on bainite structure. They are on the primary stage of transformation where bainitic ferrite laths are partially decomposed and untransformed austenite areas are transformed to martensite. Figure 3(a) shows that typical BI type ${ }^{6)}$ upper bainite formed from 

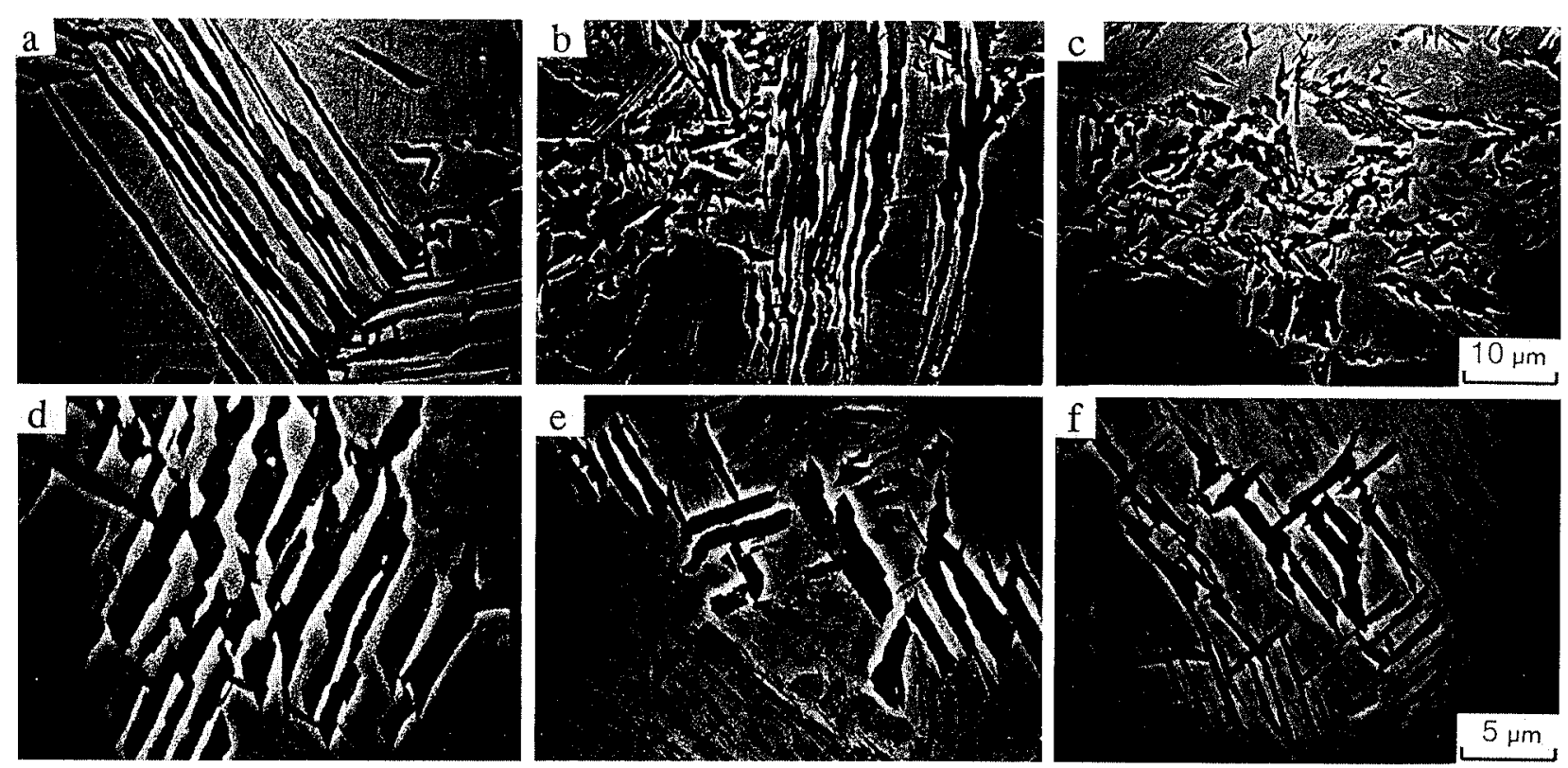

Fig. 3. Microstructures of steel 1 after $0 \%$ (a) (d), 30\% (b) (e) and $50 \%$-deformation (c) (f) at $1173 \mathrm{~K}$. Transformed at $848 \mathrm{~K}$ for 25,20 and $15 \mathrm{~s}$, respectively.

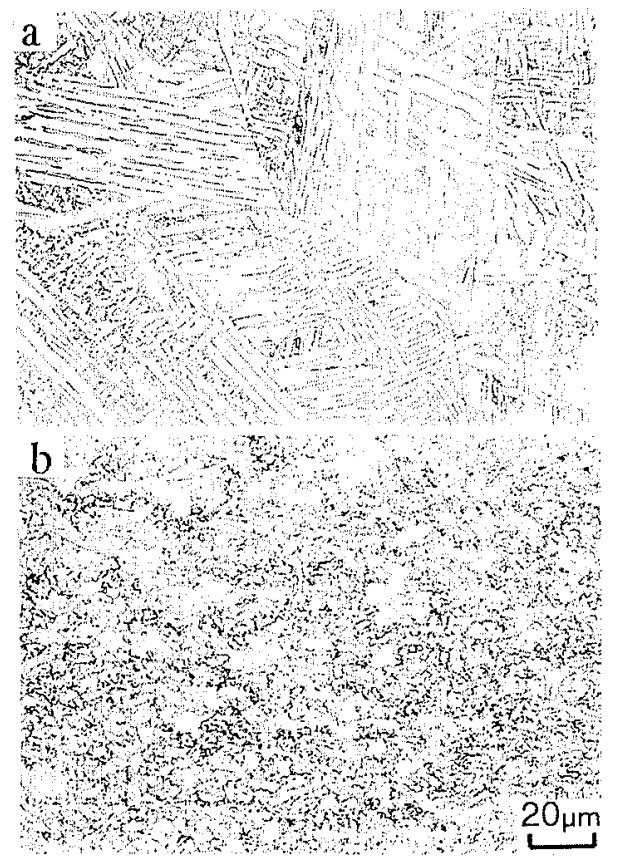

Fig. 4. Microstructures of steel 2 after $0 \%$ (a) and $75 \%$ deformation (b) at $1173 \mathrm{~K}$. Transformed at $773 \mathrm{~K}$ for 90 and $15 \mathrm{~s}$, respectively.

austenite grain boundaries without the formation of allotriomorph ferrite ${ }^{5)}$ in the case of non-deformation. In the case of 30\%-deformation (b), bainitic ferrite laths are shaped like curves of bows and their interfaces become rough. It is noteworthy that, in the case of $50 \%$-deformation (c), in contrast, the morphology of bainite structure changes significantly. The refinement of bainitic ferrite lath is observed even in steel 2 , whose carbon content are less than that of steel 1 . As can be seen in Fig. 4, in the case of non-deformation (a), large bainite packets are composed of parallel laths. However in the case of $75 \%$ deformation each bainitic ferrite lath becomes fine, and coarse bainite packets are not found.

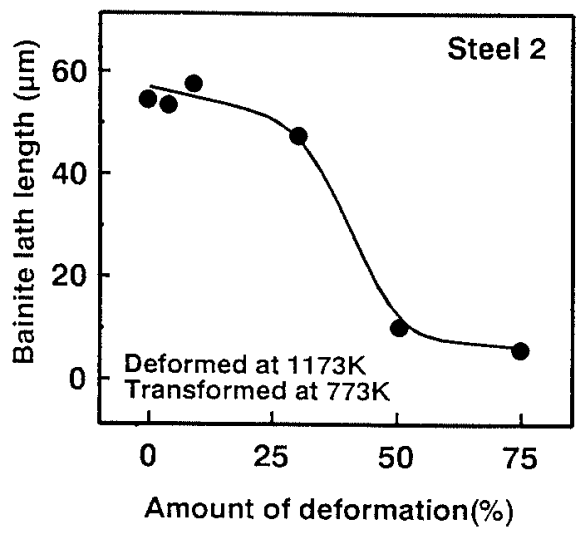

Fig. 5. Effect of deformation on the lath length transformed at $773 \mathrm{~K}$ of steel 2 .

The effect of deformation on the length of bainitic ferrite laths of steel 2 is shown in Fig. 5. It was confirmed that the deformation less than $30 \%$ was not effective on the reduction of the length, but the deformation more than $50 \%$ reduced the length significantly. This remarkable refinement of bainitic ferrite lath in the case of heavy deformation is considered to be closely related to the formation of dislocation cell structures within deformed austenite grains.

\subsubsection{Habit Planes of Bainitic Ferrite Lath De- composed from Heavily Deformed Austenite}

The detailed observation of the structures in Figs. 3(a)-3(c) shows the coalescence of parallelograms seen in Figs. 3(d)-3(f). They are considered to be the cross sections of the growth axis of bainitic ferrite laths. ${ }^{5)}$ It is confirmed that these parallelogram-like structures also exist even in the cases of 30 and $50 \%$-deformation. As previously reported, ${ }^{5}$ the bainitic ferrite laths decomposed from non-deformed austenite growth in $\langle 111\rangle_{\alpha}$ direction with two sets of habit planes between $\{110\}_{\alpha}$ and $\{451\}_{\alpha}$. TEM micrograph of partially transformed 


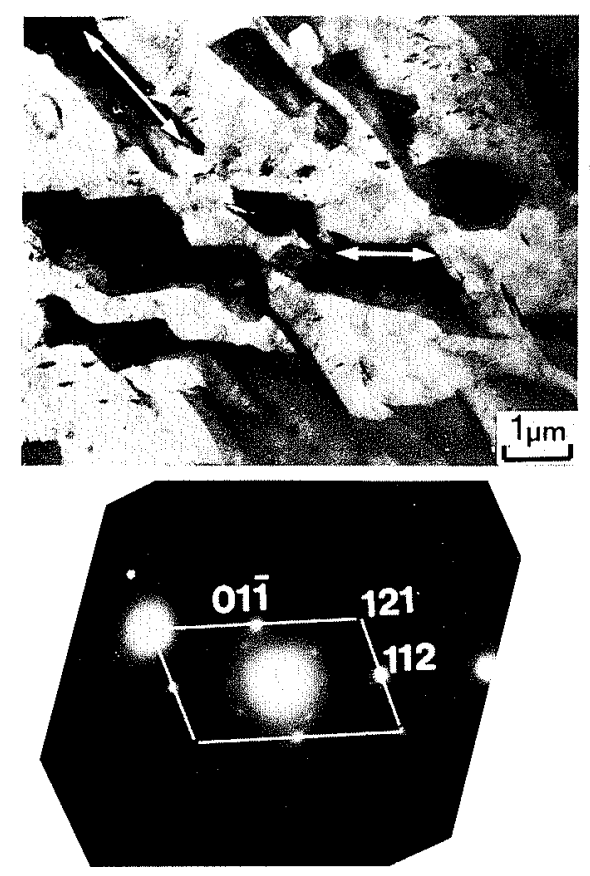

Fig. 6. Habit planes of steel 1 transformed at $773 \mathrm{~K}$ after $50 \%$-deformation.

specimen after $50 \%$-deformation is shown in Fig. 6(a). Trace analysis indicates that the habit planes of bainitic ferrite laths transformed from $50 \%$-deformed austenite also lie in the vicinity of $\{451\}_{\alpha}$. Since their growth axis were close to the normal of the micrograph in Fig. 6(b). As described above, the electron microscopical studies demonstrate that the bainitic ferrite laths developed after heavy deformation are of the similar crystallographic aspects to those from non-deformed austenite.

\subsubsection{Effects of Deformation on the Crystallographic Orientation of Banitic Ferrite Lath}

As shown in Fig. 7, in the case of non-deformation a large number of bainitic ferrite laths had same crystallographic orientation, which is the major cause of low toughness in non-deformed bainite structure. ${ }^{15,20,21)}$ In contrast, Fig. 8 describes that most of adjacent bainitic ferrite laths have different crystallographic orientations in the case of $50 \%$-deformation. In Fig. 8(a), only two pairs of laths (i.e. No. 1-2, 3-4) indicate the same orientations. It is noteworthy that the number of bainitic ferrite laths with same crystallographic orientations decreases significantly. Although single lath No. 5 is formed almost parallel to the lath No. 4, some kind of barrier prevent it from continuous growing. Actually there is a small amount of difference of orientation between No. 4 and 5 in $(1 \overline{3} \overline{3})_{\alpha}$ plane.

As described above, the heavy deformation enhances the nucleation of bainitic ferrite laths within unrecrystallized austenite grains and prevent them from continuous growth. Therefore, bainite packets consist of only a few bainitic ferrite laths. The decrease of both the length and the number of bainitic ferrite laths with same crystallographic orientation remarkably reduces the size of bainite packets, which makes the morphology of bainite considerably complicated.

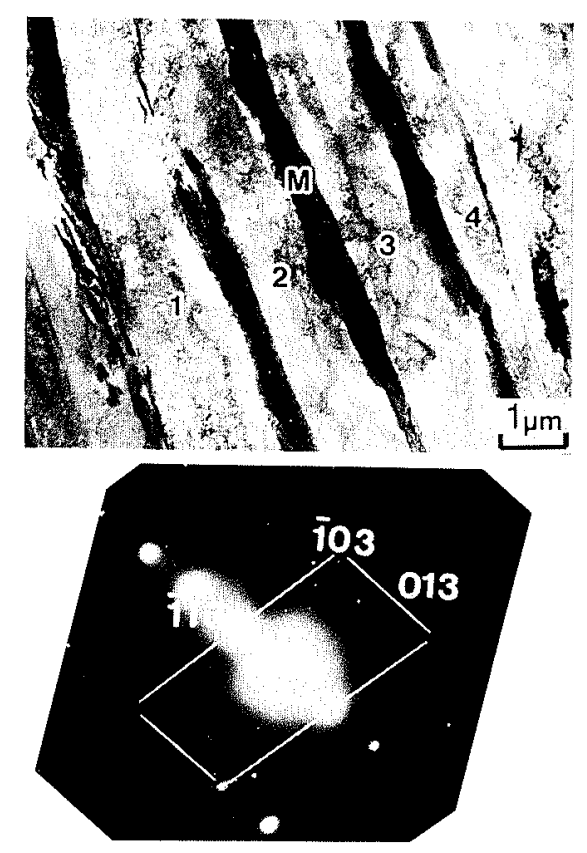

Fig. 7. Microstructure and selected area diffraction pattern of steel 1 transformed at $773 \mathrm{~K}$ without deformation.

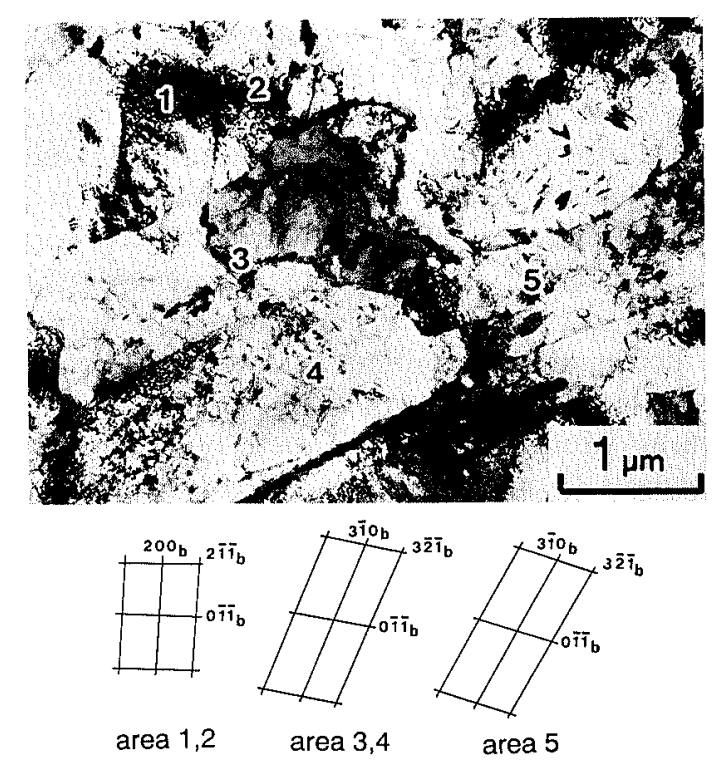

Fig. 8. Microstructure and selected area diffraction pattern of steel 1 transformed at $773 \mathrm{~K}$ after $50 \%$-deformation at $1173 \mathrm{~K}$.

\section{Discussion}

In the case of non-deformation, bainitic ferrite laths which nucleated on austenite grain boundaries grow lineally and discontinue their growth when they reach the other austenite grain boundaries. Although they are shaped like curves of bows in the case of slight deformation, bainitic ferrite laths grow and the significant decrease of the length is not found. This change of morphology of bainitic ferrite laths by the slight deformation is also reported in the studies by Edwards et $a{ }^{17{ }^{17)}}$ and Tsuzaki et al. ${ }^{19)}$ It is confirmed that, on the contrary, heavy deformation reduces their length remarkably and most of adjacent bainitic ferrite laths show different orientations. Therefore, in this case, the 
decrease of both the length and the number of bainitic ferrite laths formed in same orientation significantly reduce the size of bainite packet. As generally reported, ${ }^{22}$ ) in the case of polygonal ferrite, ferrite grain size decreases monotonously by increasing of the amount of deformation. Therefore the refinement manner of bainitic ferrite is fairly dissimilar to that of polygonal ferrite, which is considered to be closely related to the formation of dislocation cell-structures within deformed austenite grains.

As previously reported, high dislocation density is introduced into the austenite grains by the hot deformation. In the case of slight deformation these dislocations begin to tangle and shape themselves cell-like. But on this stage, these dislocation tangles are incapable to act as cell-structure boundaries. ${ }^{23-26)}$ Increasing the amount of deformation, the difference of orientations of adjacent cell-structures increase. ${ }^{23,25)}$ Moreover, in the case of heavy deformation where deformation hardening is at steady state, these cell-structures act as the boundaries in deformed austenite grains. It is also known that each cell-structure acts as an isolated grain. ${ }^{24,26)}$ Therefore, this remarkable change of the length of bainitic ferrite lath in heavy deformation leads to the refinement mechanism which is caused by the formation of cell-structures. Since, in the case of slight deformation, the dislocation density which composes cell-structure is low and the difference of orientation among adjacent cell-structures is small, bainitic ferrite laths which nucleate at grain boundaries are considered to grow beyond the dislocation tangles. Therefore, they are made grow along the distortion of austenite lattice. In contrast, in the case of heavy deformation, bainitic ferrite laths are considered to discontinue their growth at the boundaries of cellstructures. Moreover, because these boundaries act as the nucleation sites of bainitic ferrite laths, further amount of laths which has different orientation develops adjacent to each other.

As previously reported, Ahlblom et al. ${ }^{27)}$ and Liljestrand ${ }^{28)}$ measured the subgrain size of heavily deformed austenitic stainless steels. On this basis, Roberts et $a l .{ }^{29)}$ found a relationship between subgrain size $(D)$ and Zener-Hollomon parameter $(Z)$, as follows.

$$
\log D_{\text {stainless }}=2.35-0.15 \cdot \log Z
$$

where,

$$
Z=\dot{\varepsilon} \cdot \exp (Q / R T), \quad Q_{\text {stainless }}=420 \mathrm{~kJ} / \mathrm{mol}
$$

By using this, they estimated the subgrain size of low carbon steels (In their report, they treated a cell-structure as a subgrain). This shows that the subgrain size depends on the deforming temperature when strain ratio $(\dot{\varepsilon})$ is constant.

$$
D_{\text {low carbon }}=269 \cdot \exp (-4770 / T)
$$

where,

$$
\dot{\varepsilon}=1 / \mathrm{s}
$$

SEM micrographs of bainite structure fully transformed at $773 \mathrm{~K}$ after heavy deformation at several temperatures are shown in Fig. 9. As the deformation temperature is
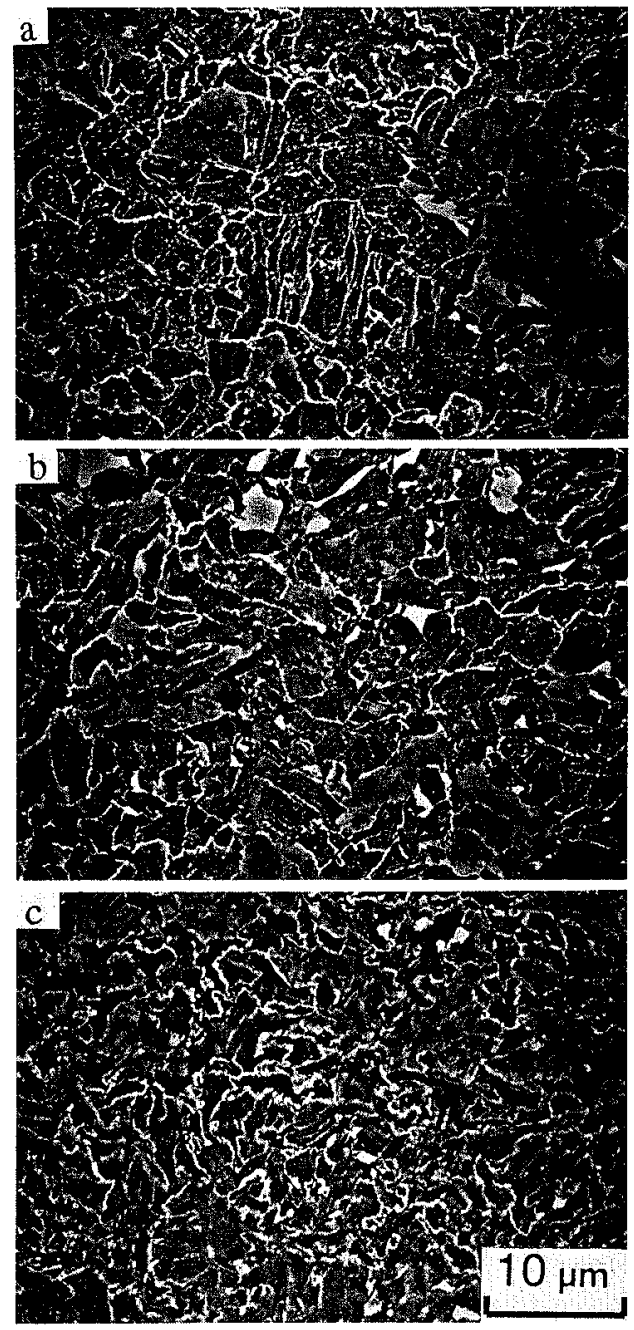

Fig. 9. SEM micrographs of steel 3 transformed at $773 \mathrm{~K}$ after deformation at $1273 \mathrm{~K}$ (a), $1173 \mathrm{~K}$ (b) and $1073 \mathrm{~K}$ (c).

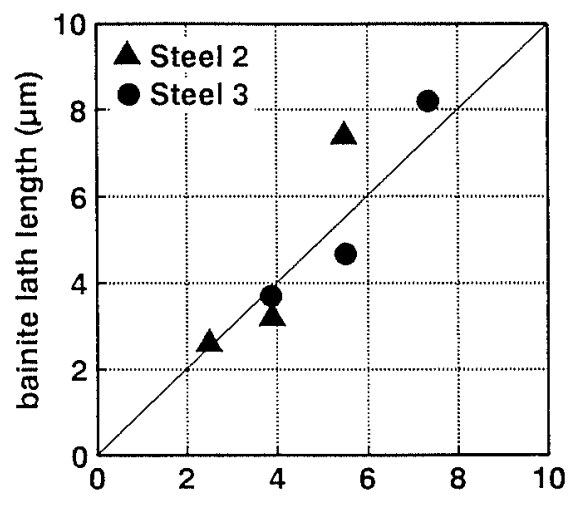

Estimated substructure size ( $\mu \mathrm{m})$

Fig. 10. Relationship between length of lath transformed from $75 \%$ deformed austenite and estimated substructure size.

lowered, the length of bainitic ferrite laths becomes short. This figure shows that the length reaches about five micrometers when the specimen was deformed at $1073 \mathrm{~K}$. The relation between the length of bainitic ferrite laths transformed from $75 \%$-deformed austenite and the estimated cell-structure size is shown in Fig. 10. This figure clearly describes that the measured length of bainitic ferrite lath consists with the estimated cell- 


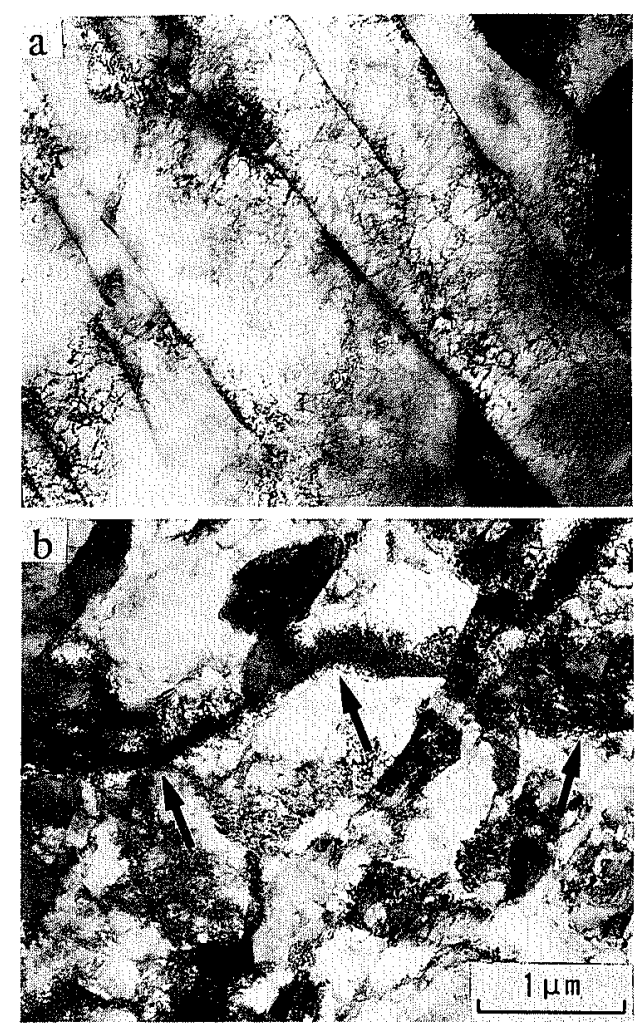

Fig. 11. High density of dislocation on the interface of laths of steel 3 transformed at $773 \mathrm{~K}$. (a) non-deformation (b) $75 \%$-deformation at $1173 \mathrm{~K}$.

structure size. This means that bainitic ferrite laths nucleate and discontinue their growth on the cell-structure boundaries within the heavily deformed austenite grains. Actually, high density of dislocation tangles which are considered to be the traces of cell-structure are observed on the interfaces of fine bainitic ferrite laths in the case of heavy deformation (See Fig. 11).

This unique manner of the refinement of bainitic ferrite lath is considered to be closely related to the transformation mechanism of bainite. As described above, it is known that grain size of polygonal ferrite is decreased monotonously by the increase of amount of deformation. This should be because polygonal ferrite is formed in diffusional mechanism. Therefore, polygonal ferrite grains grow beyond the cell-structure boundaries and erase their trace. This means that the remarkable refinement of polygonal ferrite grains is not found even in the case of heavy deformation because cell-structure boundaries have no effects to limit their size.

Even in the case of martensite formed in shear mechanism, however, the effect of deformation on the refinement of martensite lath is not as much as on that of bainitic ferrite lath. Martensite lath is able to grow beyond the dislocation cell-structure boundaries on which bainitic ferrite laths discontinue their growth. This is considered to be due to the difference of driving force between them. Therefore, martensite laths are also considered to discontinue their growth by more solid cell-structure boundary formation.

Actually, according to the previous reports concerned about ausformed martensite, there can be seen similar results as present study. Tamura et $a l^{30)}$ showed that laths of martensite are shaped like curves of bows by deformation in lower temperatures. Moreover, Araki et al. ${ }^{24)}$ described that, in the case of heavy deformation at lower temperatures, lath martensite structure became very fine and crystallographic orientation of laths were different from the adjacent laths each other.

Refinement behavior of bainite in the present study consists with that of ausformed martensite. From this viewpoint, bainitic ferrite is considered to form in the almost same manner with martensite, ${ }^{31,32)}$ and the remarkable refinement is considered to be closely related to the cell-structure formation in austenite grains.

\section{Summary}

(1) TTT diagrams of the tested steels clearly consist of two C-curves even in the case of heavy deformation.

(2) TEM micrographs of partially transformed specimen revealed that the habit planes for bainitic ferrite laths decomposed from heavily deformed austenite also lie in the vicinity of $\{451\}_{\alpha}$.

(3) Slight deformation is not effective on the reduction of the length of bainitic ferrite laths. But heavy deformation decreases the length remarkably.

(4) In the case of non-deformation, a large number of bainitic ferrite laths form parallel with the same crystallographic orientation. In contrast, in the case of heavy deformation, adjacent bainitic ferrite laths have different crystallographic orientation.

(5) The measured length of bainitic ferrite lath consists with the estimated cell-structure size. This means that bainitic ferrite laths nucleate and discontinue their growth on the cell-structure boundaries within the heavily deformed austenite grains.

\section{REFERENCES}

1) Y. Fujishiro, T. Hashimoto and H. Ohtani: Tetsu-to-Hagané, 75 (1989), 143.

2) H. Ohtani, S. Okaguchi, Y. Fujishiro and Y. Ohmori: Metall. Trans., 21A (1990), 877.

3) D. V. Edmonds and R. C. Cochrane: Metall. Trans., 21A (1990), 1527.

4) R. F. Hehemann, K. R. Kinsman and H. I. Aaronson: Metall. Trans., 2 (1972), 1077.

5) S. Okaguchi, H. Ohtani and Y. Ohmori: Mater. Trans. JIM, 32 (1991), 697.

6) Y. Ohmori, H. Ohtani and T. Kunitake: Trans. Iron Steel Inst. Jpn., 11 (1971), 250.

7) R. F. Mehl: Hardenability of Alloy Steels, ASM, Cleveland, OH, (1939), 1. [ASM]

8) T. Ko and S. A. Cottrel: J. Iron Steel Inst., 172 (1952), 307.

9) B. L. Bramfitt and J. G. Speer: Metall. Trans., 21A (1990), 817.

10) S. Watanabe, H. Ohtani, K. Sakai and H. Uchimura: Tetsuto-Hagané, 66 (1980), 253.

11) S. Okaguchi, K. Fujiwara and T. Hashimoto: Proc. of Symp. Mat. Week '92, TMS, Chicago, 169.

12) T. Araki, M. Enomoto and K. Shibata: Mater. Trans. JIM, 32 (1991), 729.

13) T. Inoue: Trans. JIM, 11 (1970), 36

14) F. Terasaki, H. Ohtani and T. Kunitake: Tetsu-to-Hagané, 58 (1972), 293.

15) H. Ohtani, F. Terasaki and T. Kunitake: Trans. Iron Steel Inst. Jpn., 12 (1972), 118.

16) R. Freiwillig, J. Kudrman and P. Chraska: Metall. Trans., 7A (1976), 1091.

17) R. H. Edwards and N. F. Kennon: Metall. Trans., 9A (1978), 1801. 
18) M. Umemoto, S. Bando and I. Tamura: Proc. Int. Conf. on Martensitic Transformations, ICOMAT86, Kyoto, Japan Inst. Met., (1986), 595.

19) K. Tsuzaki, T. Ueda, K. Fujiwara and T. Maki: New Materials and Processes for the Future, Proc. 1st Japan Int. SAMPE Symp. and Exhib., Soc. for Advancement of Mater. and Process Eng., Chiba, Japan, (1989), 799.

20) F. B. Pickering: Transformation and Hardenability in Steels, Climax Molybdenum, Ann. Arbor, MI, (1967), 109.

21) T. Kunitake, F. Terasaki, Y. Ohmori and H. Ohtani: Iron Steel, 45 (1972), 647.

22) H. Sekine and T. Maruyama: Seitetsu Kenkyu, 289 (1976), 43.

23) H. J. McQeen: Metall. Trans., 8A (1977), 807.

24) T. Araki, T. Watanabe and H. Miyaji: Toward Improved Ductility and Toughness, Climax Molybdenum (Japan) Ltd., (1971), 173.

25) H. J. McQeen and J. J. Jones: Treatise Mater. Sci. Technol., 6
(1975), 393

26) J. E. Bailey: Electron Microscopy and Strength of Crystals, Wiley Interscience, New York, (1963), 535.

27) B. Ahlblom and W. Roberts: Dr. Thesis, Royal Institute of Technology, Stockholm, (1977).

28) L. G. Liljestand: Scand. J. Metall., 1 (1972), 271.

29) W. Roberts and B. Ahlblom: Acta Metall., 26 (1978), 801.

30) I. Tamura, K. Tsuzaki and T. Maki: Proc. Int. Conf. on Martensitic Transformations, ICOMAT86, Kyoto, Japan Inst. Met., (1986), 551.

31) Y. Ohmori and T. Maki: Mater. Trans., JIM, 32 (1991), 631.

32) K. Tsuzaki, K. Fujiwara and T. Maki: Mater. Trams., JIM, 32 (1991), 667.

(Originally published in Tetsu-to-Hagané, 80(1994), 771, in Japanese) 